Received Date : 09-Nov-2015

Revised Date : 15-Apr-2016

Accepted Date : 25-May-2016

Article type : Reports

\title{
Stream drying drives microbial ammonia oxidation and first flush nitrate export
}

\author{
Merbt $\mathrm{SN}^{1}$, Proia $\mathrm{L}^{3 / 6}$, Prosser $\mathrm{JI}^{4}$, Martí $\mathrm{E}^{2}$, Casamayor $\mathrm{EO}^{2}$, von Schiller $\mathrm{D}^{5}$
}

${ }^{1}$ Eawag: Swiss Federal Institute of Aquatic Science and Technology (EAWAG), Department of Environmental Toxicology, Überlandstrasse 133 Postfach 611, 8600 Dübendorf, Switzerland

${ }^{2}$ Integrative Freshwater Ecology Group, Centre d'Estudis Avançats de Blanes, CEAB-CSIC, Accés a la Cala St. Francesc 14, 17300 Blanes, Spain

${ }^{3}$ Catalan Institute for Water Research, Emili Grahit 101, 17003 Girona, Spain

${ }^{4}$ Institute of Biological and Environmental Sciences, University of Aberdeen, Cruickshank Building, St Machar Drive, Aberdeen, AB24 3UU, UK

${ }^{5}$ Department of Plant Biology and Ecology, Faculty of Science and Technology, University of the Basque Country. PO Box 644, 48080 Bilbao, Spain

${ }^{6}$ Ecology of Aquatic Systems, Université Libre de Bruxelles. Boulevard du Triomphe

B-1050 Bruxelles.

Running head: Ammonia oxidation in dry riverbeds.

Corresponding author: Merbt SN, Email: Stephanie.Merbt@eawag.ch; Tel: +41 58765 5021

This article has been accepted for publication and undergone full peer review but has not been through the copyediting, typesetting, pagination and proofreading process, which may lead to differences between this version and the Version of Record. Please cite this article as doi: 10.1002/ecy.1486

This article is protected by copyright. All rights reserved. 


\begin{abstract}
Stream microbial communities and associated processes are influenced by environmental fluctuations that may ultimately dictate nutrient export. Discharge fluctuations caused by intermittent stream flow are increasing worldwide in response to global change. We examined the impact of flow cessation and drying on in-stream nitrogen cycling. We determined archaeal (AOA) and bacterial ammonia oxidiser (AOB) abundance and ammonia oxidation activity in surface and deep sediments from different sites along the Fuirosos stream (Spain) subjected to contrasting hydrological conditions (i.e. running water, isolated pools and dry streambeds). AOA were more abundant than AOB, with no major changes across hydrological conditions or sediment layers. However, ammonia oxidation activity and sediment nitrate content increased with the degree of stream drying, especially in surface sediments. Upscaling of our results shows that ammonia oxidation in dry streambeds can contribute considerably $(\sim 50 \%)$ to the high nitrate export typically observed in intermittent streams during first flush events following flow reconnection. Our study illustrates how the dry channels of intermittent streams can be potential hotspots of ammonia oxidation.

Consequently, shifts in the duration, spatial extent and severity of intermittent flow can play a decisive role in shaping nitrogen cycling and export along fluvial networks in response to global change.
\end{abstract}

Keywords: semiarid ecosystems, intermittent flow, stream, dry riverbed, nitrification, ammonia oxidation, AOA, AOB

\title{
INTRODUCTION
}

Environmental variability can significantly modify the activity of microorganisms and often alters ecosystem functioning (Schimel et al. 2007). A major fluctuation in freshwater ecosystems is variation in water supply. In intermittent streams this can lead to flow cessation, the formation of isolated pools and ultimately to stream desiccation and the emergence of dry sediments, with strong concomitant changes in biogeochemistry and microbial composition (Fazi et al. 2013, Febria et al. 2015). Intermittent streams subjected to these hydrological fluctuations are common ecosystems worldwide, comprising over half the channel length of the world's river networks (Datry et al. 2014). In addition, their spatial and temporal extent is increasing in many areas due to the combined effects of altered land-use patterns and climate change.

The sediments of isolated pools are exposed to stagnant water conditions and tend to become oxygen-limited (Lillebø et al. 2007). By contrast, dry stream sediments become fully exposed to the atmosphere and environmental conditions tend to be similar to those of soils in adjacent terrestrial ecosystems (Steward et al. 2012). Once surface flow returns, stream water solute concentrations in first flush events rise dramatically, leading to the export of high amounts of nitrogen $(\mathrm{N})$ mainly in the form of nitrate (von Schiller et al. 2011). N export may

This article is protected by copyright. All rights reserved. 
be influenced by inputs from the catchment, but also by in-stream microbial activity in streambed sediments prior to inundation. Despite the global prevalence of intermittent streams and the importance of in-stream processes for $\mathrm{N}$ cycling (Mulholland and Webster 2010), our mechanistic understanding of the effects of intermittent flow on $\mathrm{N}$ cycling patterns remains limited (Steward et al. 2012, Datry et al. 2014).

Nitrification, the oxidation of ammonia to nitrate via nitrite, is a key process in the global $\mathrm{N}$ cycle. In streams, nitrification is important in reducing potentially inhibitory effects of ammonia from fertiliser run-off or mineralisation of organic matter (Merbt et al. 2015). Ammonia oxidation is usually the first and rate-limiting step of nitrification and is carried out by ammonia oxidising archaea (AOA) and bacteria (AOB), each with a specific range of ecophysiological adaptations (Fernàndez-Guerra and Casamayor 2012). In soils, drought has been shown to affect activity of ammonia oxidisers due to limited substrate supply and the induction of physiological disruptions associated with cell dehydration during drying (Stark and Firestone 1995, Thion and Prosser 2014). In streams, an increase in sediment nitrate content with increasing moisture stress has been reported in a field study (Gómez et al. 2012). However, a negative effect of drying on ammonia oxidation was found in a laboratory study of ammonia oxidation rates in rewetted sediments (Austin and Strauss 2011). Despite the importance of ammonia oxidisers in the $\mathrm{N}$ cycle, there is limited knowledge of how ammonia oxidation and the presence and activity of its main microbial players, i.e. AOA and AOB, are affected by the large fluctuations in environmental conditions that occur in sediments of intermittent streams. However, this knowledge may provide valuable mechanistic information on the observed increases in $\mathrm{N}$ export during flow reconnection in intermittent streams (Bernal et al. 2013).

This study was designed to explore the effects of intermittent flow on in-stream microbial ammonia oxidation and its potential consequences for nitrate export during first flush events. We hypothesised that the abundance and activity of ammonia oxidisers is fostered by the increase in diffusive oxygen exchange into the pore space of the stream sediments resulting from flow desiccation. Thus, we predict greater AOA and AOB abundance and activity in dry than in wet stream channels, leading to higher nitrate accumulation in sediments of dry channels. Additionally, we expect these changes to be more pronounced in surface than in deep sediment layers due to more stable environmental conditions in the latter. To test this, we examined the surface and deep sediment layers of five sites, representing different hydrological phases, in an intermittent stream. Finally, we used an empirical upscaling approach to test the hypothesis that nitrate generated via ammonia oxidation and accumulated in dry stream sediments during the non-flow phase contributes considerably to nitrate export from the catchment during first flush events.

This article is protected by copyright. All rights reserved. 


\section{METHODS}

Study site: Five sites representing different hydrological regimes were sampled along a 6-km stretch (82 m - 200 m a.s.1.) of the Fuirosos stream in summer (26-29 July, 2013). Furiosos is a well-studied intermittent stream in the NE Iberian Peninsula with minor human activity, draining a forested catchment dominated by siliceous geology (Vazquez et al. 2013). Sandy sediments are the dominant substratum. The Fuirosos stream dries up in summer along most of its length, with downstream reaches drying first. The length of the non-flow phase can vary among years and along the stream, but on average flow ceases for more than one month along most of the stream network (Vazquez et al. 2013). Within this context, the following sampling sites (distributed from upstream to downstream, see supporting information for coordinates) were identified to represent different hydrological phases that characterize the stream conditions during summer drought: i) a reach with flowing surface water (running water site); ii) a pool with standing water that had been disconnected for 5 days (short-term pool site); iii) a pool with standing water that had been disconnected for 30 days (long-term pool site); iv) a reach with surface water absent for 5 days (short-term dry site), and iv) a reach with surface water absent for 30 days (long-term dry site).

Sample collection and analysis: At each site, sandy sediments from both surface (0 - 2 $\mathrm{cm})$ and deep sediment layers $(7-10 \mathrm{~cm})$ were collected and sieved $(2 \mathrm{~mm}$ mesh size $)$ at three randomly selected locations. At the sites with surface water, dissolved oxygen (DO) concentration and $\mathrm{pH}$ were measured using hand-held sensors and water samples were taken and filtered in situ for nutrient analyses. Sediment gravimetric water content, dry weight (DW) and ash-free dry mass (AFDM) were determined by weighing sediment samples before and after drying and ashing. Sediment $\mathrm{pH}$ was measured by preparing a sediment suspension in de-ionized water. Sediment ammonia + ammonium (hereafter ammonia) and nitrate + nitrite (hereafter nitrate) content were determined colorimetrically after $1 \mathrm{M} \mathrm{KCl}$ extraction and expressed $\mathrm{g}^{-1} \mathrm{DW}$.

Sediment samples for DNA analysis were frozen in the field with liquid $\mathrm{N}$ and stored at $-80^{\circ} \mathrm{C}$ in the laboratory. DNA extraction was carried out using the MOBIO Power soil extraction kit (see details in supporting information). AOA and AOB abundances were estimated by real-time polymerase chain reaction amplification of amoA genes using specific primers for AOA and AOB (Rotthauwe et al. 1997, Francis et al. 2005 and see supporting information).

The amount of oxidized ammonia in each sediment was determined using the acetylene-inhibition method, which allowed application of the same method for inundated and dry conditions (Offre et al. 2009). Immediately after sampling, sediments (30 g wet weight) from each replicate sample was placed in each of two $250 \mathrm{~mL}$ flasks, one inhibited and one control, along with $30 \mathrm{~mL}$ unfiltered stream water in sediments from inundated sites or no addition to sediments from dry sites. Acetylene (100 Pa) was added to the inhibited flask to inhibit ammonia oxidation (Offre et al. 2009). Extractable ammonia and nitrate concentrations in the sediments were measured, as described above, after shaking incubation in the dark $\left(175 \mathrm{rpm}, 25^{\circ} \mathrm{C}, 42 \mathrm{~h}\right)$. All incubations were carried out in triplicate. The amount 
of ammonia that was oxidized was calculated as the difference in extractable ammonia between the inhibited and control flasks after incubation and was expressed $\mathrm{g}^{-1}$ sediment DW (Levi et al. 2013).

Data analysis: To test the null hypothesis of no effect of sediment layer and water content on the response variables, we used generalized least squares (GLS) models with the interaction between the factor sediment layer and the covariable water content. To deal with observed heterocedasticity, we used the argument "weights" within the function gls(), and the functions varIdent () and $\operatorname{varExp}()$ to specify variance models with different variances for each of the two levels of the factor sediment with an exponential function of the variance for water content. The GLS models were fit by restricted maximum likelihood (REML). The difference in water content between sediment layers and the difference between AOA and AOB abundance were tested with Student's $t$-tests. Statistical analyses were done using the "nmle" package (Pinheiro et al. 2016) in the R software v. 3.2.3 (R Core Team 2015).

\section{RESULTS AND DISCUSSION}

The observed variability in physical and chemical conditions across study sites covered the range of temporal variability previously observed at specific sites in the same stream during the drying process (von Schiller et al. 2011). The long- and short-term pool sites showed similar surface water DO concentration (range $1.45-1.85 \mathrm{mg} \mathrm{L}^{-1}$ ) and $\mathrm{pH}$ (range 6.68 - 6.74). These values were substantially lower than those from the running water site (DO $=7.09 \mathrm{mg} \mathrm{L}^{-1} ; \mathrm{pH}=7.22$ ), a common consequence of flow fragmentation (von Schiller et al. 2011). Water column ammonium and nitrate concentrations were higher in the running water site $\left(0.172 \mathrm{mg} \mathrm{N}-\mathrm{NH}_{4}{ }^{+} \mathrm{L}^{-1}\right.$ and $0.777{\mathrm{mg} \mathrm{N}-\mathrm{NO}_{3}}^{-} \mathrm{L}^{-1})$ than in the long-term

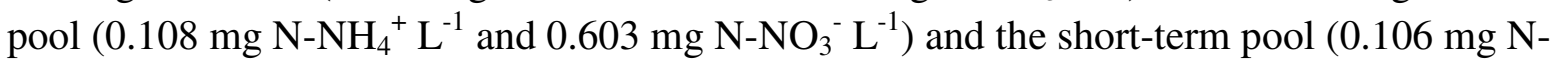
$\mathrm{NH}_{4}{ }^{+} \mathrm{L}^{-1}$ and $\left.0.242 \mathrm{mg} \mathrm{N}-\mathrm{NO}_{3}{ }^{-} \mathrm{L}^{-1}\right)$.

The effects of drying were reflected in the sediment water content, which decreased from $>20 \%(\mathrm{w} / \mathrm{v})$ at the inundated sites to $<12 \%$ in the short-term dry site and $<2 \%$ at the long-term dry site (Fig. 1). There was no significant difference in water content between surface and deep sediment layers ( $t$-test, $p=0.875$ ), as previously observed for this stream during the dry phase (Timoner et al. 2012), presumably reflecting the effects of dew and water capillarity from deeper water layers. Surface and deep sediments did not differ in organic matter content or $\mathrm{pH}$ and the changes in water content had no effect on the variation of these two variables (Fig. 1A and B). In contrast, the ammonia content in surface sediment increased with drying more than did deep sediments (Fig. 1C), and the nitrate content increased with drying in both sediment layers (Fig. 1D). At all sites, ammonia and nitrate contents were in the ranges previously reported for sediments from other freshwater systems with low human impact (Damashek et al. 2014, Bollmann et al. 2014). The increase in ammonia content with drying was expected as a consequence of desiccation-induced cell lysis and water evaporation from the sediments (Stark and Firestone 1995) presumably due to

This article is protected by copyright. All rights reserved. 
mineralization of organic matter. The increase in nitrate content most likely indicates nitrate accumulation derived from ammonia oxidation in dry sediments (Gómez et al. 2012).

The concentration of ammonia has been proposed to be a driving factor for abundance and activity of ammonia oxidisers (Martens-Habbena et al. 2009, Prosser and Nicol 2012). Therefore, we expected that, if changes in the hydrological conditions involve changes in ammonia content, then these differences would induce a shift in the relative abundances of $\mathrm{AOA}$ and $\mathrm{AOB}$ and their activity within the sediments. However, despite the increase in ammonia availability with desiccation in surface sediments (Fig. 1C), the abundance of AOA was similar in surface and deep sediments and did not vary with changes in sediment water content (Fig. 2A). Only AOB abundance followed the increase in ammonia availability with drying in surface sediments (Fig, 2B). However, mean AOA abundance was 8-fold higher than mean AOB abundance (paired $t$-test, $p=0.002$; Fig. $2 \mathrm{~A}$ and B). At the inundated sites, the dominance of $\mathrm{AOA}$ over $\mathrm{AOB}$ is in agreement with previous studies from relatively low ammonia environments and may be explained by higher ammonia affinity of AOA with respect to AOB (Martens-Habbena et al. 2009, Bollmann et al., 2014).

Overall, our results indicate that the abundance of ammonia oxidisers, especially AOA, in stream sediments is not significantly affected by hydrological conditions in stream channels, which suggests a high capacity of ammonia oxidisers to resist drying conditions in intermittent streams. This finding supports other studies showing the capacity of some microbes to resist sediment desiccation and minor differences in microbial community composition between intermittent and perennial streams (Timoner et al. 2014, Febria et al. 2015). Nonetheless, more physiological studies on AOA and AOB as part of complex microbial communities within stream sediments are necessary to predict in situ community composition and increase understanding of driving factors.

Despite the lack of strong differences in the abundance of ammonia oxidisers, the amount of oxidized ammonia clearly increased with sediment dessication irrespective of the sediment layer considered (Fig. 2C). This result is in line with the observed concomitant increase in nitrate content with dessication (Fig. 1D), supporting the role of dry sediments as hotspots of ammonia oxidation (Gómez et al. 2012). Moreover, together with the observations of AOA and AOB abundances, these results reveal the high capacity of AOA and $\mathrm{AOB}$ to persist in stream sediments under different hydrologic conditions while significantly changing their activity in response to those changes in environmental conditions (Placella and Firestone 2013). Among others, the desiccation process enhances diffusive oxygen exchange into the highly heterogeneous pore space of the sediments, which seemed to trigger ammonia oxidation. Accordingly, nitrification has been shown to be highest at $60 \%$ water-filled pore space in soils (Bateman and Baggs 2005), suggesting oxygen as one limiting factor for the activity of ammonia oxidation in sediments of inundated stream channels.

Our results partly contradict previous findings from soils, where potential rates of ammonia oxidation declined with decreasing water availability (Stark and Firestone 1995, Chen et al. 2011). However, the increase of the ammonia oxidising activity in soils has been shown to depend on the severity and duration of the dry period, and complete saturation of 
water has seldom be tested in soils (Fierer and Schimel 2002). Therefore, in the study stream, which is commonly subjected to non-flow conditions, the sediments provide optimal conditions for increased activity of ammonia oxidisers at least after one month without surface water. The significant increase in nitrate concentration in the sediments during the non-flow phase as a consequence of increased ammonia oxidation could thus provide a mechanistic explanation of the in-stream control of the high first flush nitrate export typically observed in intermittent streams after flow reconnection (von Schiller et al. 2011).

To evaluate the potential contribution of ammonia oxidation in dry stream sediments to total nitrate export during first flush events, we first averaged the extractable nitrate content of deep and surface sediments at long-term dry sites $\left(3.7 \mu \mathrm{g} \mathrm{N} \mathrm{g} \mathrm{DW}^{-1}\right)$ and multiplied it by the sediment weight per stream area $\left(124 \mathrm{~kg} \mathrm{DW} \mathrm{m}^{-2}\right.$; Merbt et al. unpublished data) to obtain the areal mean sediment nitrate content $\left(461 \mathrm{~g} \mathrm{~N} \mathrm{~m}^{-2}\right)$. This value was then multiplied by the total area of the Fuirosos stream channel network ( 2.3 ha; Bernal et al. 2012; Fig 3A) and the average \% channel area occupied by sand (60\%; von Schiller et al. 2011) to estimate the mass of nitrate potentially accumulated in the sediments of the Fuirosos stream during the dry period. These data were compared to the estimated mass of nitrate that passed during a 6-day first flush after flow reconnection at the outlet of the Fuirosos catchment (13.3 kg N; from von Schiller et al. 2011; Fig 3B). Our estimates showed that the nitrate accumulated in dry stream sediments could contribute nearly $50 \%$ of the first flush nitrate export from the Fuirosos catchment (6.4 kg N, Fig 3C). Despite high interannual variability, first flushes in the Fuirosos stream can account for over 5\% of the total annual nitrate export (Bernal et al. 2005), and studies in other Mediterranean and semiarid streams have reported the highest nitrate peaks following the summer drought (Bernal et al. 2013). Our results emphasise dry sediments as hotspots for nitrate production and storage, which should be taken into account when estimating nitrate sources and sinks for the entire watershed.

Temporal dynamics of $\mathrm{N}$ concentrations in streams depend on the influence of both terrestrial and in-stream processes (Mulholland and Webster 2010). Here, we provide empirical evidence that flow cessation and drying in intermittent streams can strongly influence these dynamics by altering microbial processes in streambed sediments. In particular, our experimental data and upscaling approach illustrate how the dry channels of intermittent streams can be potential hotspots of ammonia oxidation, with important consequences for overall $\mathrm{N}$ cycling and transport along fluvial networks. Predicted effects of variability in ammonia concentration among sites derived from sediment desiccation conditions on $\mathrm{AOA}$ and $\mathrm{AOB}$ abundances were not observed, suggesting that the high resistance of these communities is dependent on other factors. However, we showed that changes in sediment ambient conditions induced by flow cessation and desiccation may induce changes in the activities of AOA and AOB, which can further result in changes in ammonia oxidation at reach scale, thereby causing accumulation of nitrate in dry sediments and high nitrate export at first flush events. Overall, our findings indicate that shifts in the duration, spatial extent and severity of intermittent flow can play a decisive role in shaping $\mathrm{N}$ cycling and export along fluvial networks in response to global change.

This article is protected by copyright. All rights reserved. 


\section{ACKNOWLEDGMENTS}

We thank Roser Ventosa for technical assistance at the Nutrient Analytical Service of the CEAB-CSIC and Iñaki Odriozola and Aitor Larrañaga for statistical advice. We also acknowledge two anonymous reviewers for valuable feedback and constructive comments on the manuscript. SNM was supported by a JAE predoctoral fellowship from the Spanish National Research Council (CSIC). This research was granted by the projects DARKNESS (CGL2012-32747, MINECO) to EOC and MED_FORESTREAM (CGL2011-30590-CO202, MINECO) and REFRESH (244121 FP7 EU Commission) to EM.

\section{REFERENCE LIST}

Austin, B. J., and E. A. Strauss. 2011. Nitrification and denitrification response to varying periods of desiccation and inundation in a western Kansas stream. Hydrobiologia 658:183-195.

Bateman, E. J., and E. M. Baggs. 2005. Contributions of nitrification and denitrification to $\mathrm{N} 2 \mathrm{O}$ emissions from soils at different water-filled pore space. Biology and Fertility of Soils 41:379-388.

Bernal, S., A. Butturini, and F. Sabater. 2005. Seasonal variations of dissolved nitrogen and DOC:DON ratios in an intermittent Mediterranean stream. Biogeochemistry 75:351372.

Bernal, S., D. von Schiller, E. Martí, and F. Sabater. 2012. In-stream net uptake regulates inorganic nitrogen export from catchments under base flow conditions. Journal of Geophysical Research 117:G00N05.

Bernal, S., D. von Schiller, F. Sabater, E. Martí. 2013. Hydrological extremes modulate nutrient dynamics in mediterranean climate streams across different spatial scales. Hydrobiologia 719: 31-42.

Bollmann, A., G. S. Bullerjahn, and R. M. McKay. 2014. Abundance and diversity of ammonia-oxidizing archaea and bacteria in sediments of trophic end members of the Laurentian Great Lakes, Erie and Superior. PLoS ONE 9:e97068.

Chen, Y.-T., W. Borken, C. F. Stange, and E. Matzner. 2011. Effects of decreasing water potential on gross ammonification and nitrification in an acid coniferous forest soil. Soil Biology and Biochemistry 43:333-338.

Damashek, J., J. M. Smith, A. C. Mosier, and C. A. Francis. 2014. Benthic ammonia oxidizers differ in community structure and biogeochemical potential across a riverine delta. Frontiers in Microbiology 5:743.

Datry, T., S. T. Larned, and K. Tockner. 2014. Intermittent Rivers: A challenge for freshwater ecology. BioScience 64:229-235.

This article is protected by copyright. All rights reserved. 
Fazi S, Vázquez E, Casamayor EO, Amalfitano S, Butturini A (2013) Stream Hydrological Fragmentation Drives Bacterioplankton Community Composition. PLoS ONE 8(5): e64109.

Febria, C. M., J. D. Hosen, B. C. Crump, M. A. Palmer, and D. D. Williams. 2015. Microbial responses to changes in flow status in temporary headwater streams: a cross-system comparison. Frontiers in Microbiology 6:522.

Fernàndez-Guerra, A., and E. O. Casamayor. 2012. Habitat-associated phylogenetic community patterns of microbial ammonia oxidizers. PloS one 7:22-26.

Fierer, N., and J. P. Schimel. 2002. Effects of drying-rewetting frequency on soil carbon and nitrogen transformations. Soil Biology and Biochemistry 34:777-787.

Francis, C. A., K. J. Roberts, J. M. Beman, A. E. Santoro, and B. B. Oakley. 2005. Ubiquity and diversity of ammonia-oxidizing archaea in water columns and sediments of the ocean. Proceedings of the National Academy of Sciences of the United States of America 102:14683-14688.

Gómez, R., M. I. Arce, J. J. Sánchez, and M. del Mar Sánchez-Montoya. 2012. The effects of drying on sediment nitrogen content in a Mediterranean intermittent stream: a microcosms study. Hydrobiologia 679:43-59.

Levi, P. S., J. L. Tank, S. D. Tiegs, D. T. Chaloner, and G. A. Lamberti. 2013.

Biogeochemical transformation of a nutrient subsidy: salmon, streams, and nitrification. Biogeochemistry 113:643-655.

Lillebø, A. I., M. Morais, P. Guilherme, R. Fonseca, A. Serafim, and R. Neves. 2007. Nutrient dynamics in Mediterranean temporary streams: a case study in Pardiela catchment (Degebe River, Portugal). Limnologica-Ecology and Management of Inland Waters 37:337-348.

Martens-Habbena, W., P. M. Berube, H. Urakawa, R. José, and D. A. Stahl. 2009. Ammonia oxidation kinetics determine niche separation of nitrifying Archaea and Bacteria. Nature 461:976-979.

Merbt, S. N., J.-C. Auguet, A. Blesa, E. Martí, and E. O. Casamayor. 2015. Wastewater treatment plant effluents change abundance and composition of ammonia-oxidizing microorganisms in Mediterranean urban stream biofilms. Microbial ecology 69:66-74.

Mulholland, P. J., and J. R. Webster (2010). Nutrient dynamics in streams and the role of JNABS. Journal of the North American Benthological Society 29:100-117.

Offre, P., J. I. Prosser, and G. W. Nicol. 2009. Growth of ammonia-oxidizing archaea in soil microcosms is inhibited by acetylene. FEMS Microbiology Ecology 70:99-108.

Pinheiro, J., D. Bates, S. DebRoy, D. Sarkar, and R Core Team (2016). nlme: Linear and nonlinear mixed effects models. R package version 3.1-126, http://CRAN.R-

This article is protected by copyright. All rights reserved. 
project.org/package=nlme.

Placella, S. A., and M. K. Firestone. 2013. Transcriptional response of nitrifying communities to wetting of dry soil. Applied and Environmental Microbiology 79:3294-3302.

Prosser, J. I., and G. W. Nicol. 2012. Archaeal and bacterial ammonia oxidisers in soil: the quest for niche specialisation. Trends in Microbiology 20:523-531.

R Core Team, 2015. R: A Language and Environment for Statistical Computing. R Foundation for Statistical Computing, Vienna, Austria.

Rotthauwe, J.-H., K.-P. Witzel, and W. Liesack. 1997. The ammonia monooxygenase structural gene amoA as a functional marker: molecular fine-scale analysis of natural ammonia-oxidizing populations. Applied and Environmental Microbiology 63:47044712.

von Schiller, D., V. Acuña, D. Graeber, E. Martí, M. Ribot, S. Sabater, X. Timoner, and K. Tockner. 2011. Contraction, fragmentation and expansion dynamics determine nutrient availability in a Mediterranean forest stream. Aquatic sciences 73:485-497.

Schimel, J., T. C. Balser, and M. Wallenstein. 2007. Microbial stress-response physiology and its implications for ecosystem function. Ecology 88:1386-1394.

Stark, J. M., and M. K. Firestone. 1995. Mechanisms for soil moisture effects on activity of nitrifying bacteria. Applied and Environmental Microbiology 61:218-221.

Steward, A. L., D. von Schiller, K. Tockner, J. C. Marshall, and S. E. Bunn. 2012. When the river runs dry: human and ecological values of dry riverbeds. Frontiers in Ecology and the Environment 10:202-209.

Thion, C., and J. I. Prosser. 2014. Differential response of non-adapted ammonia oxidising archaea and bacteria to drying rewetting stress. FEMS Microbiology Ecology.

Timoner, X., V. Acuna, D. von Schiller, and S. Sabter. 2012. Functional responses of stream biofilms to flow cessation, desiccation and rewetting. Freshwater Biology 57:15651578.

Timoner, X., C. M. Borrego, V. Acuña, and S. Sabater. 2014. The dynamics of biofilm bacterial communities is driven by flow wax and wane in a temporary stream. Limnol. Oceanogr 59:2057-2067.

Vazquez, E., V. Acuña, J. Artigas, S. Bernal, E. Ejarque, A. Gaudes, I. Ylla, E. Martí, E. Mas-Martí, and A. Guarch. 2013. Fourteen years of hydro-biogeochemical monitoring in a Mediterranean catchment. Die Bodenkultur 13:3-4.

This article is protected by copyright. All rights reserved. 


\section{Figure legends:}

Figure 1: Sediment organic matter content (panel A), pH (panel B), ammonia content (panel C) and nitrate content (panel D) as a function of water content in surface (white symbols) and deep (black symbols) sediments at running water (circle), short-term pool (triangle down), long-term pool (square), short-term dry (diamond), and long-term dry (triangle up) sites. Mean values and standard errors are shown. Results from GLS models with sediment layer as treatment and water content as covariate are shown. Statistically significant effects $(p<0.05)$ are marked in bold. Straight lines describe the fits of the GLS models between the response variables and the interaction between the factor and the covariable. Non significant effects are omitted.

Figure 2: Abundance of archaeal (panel A) and bacterial (panel B) amoA gene $\mathrm{g}^{-1}$ sediment dry weight and the amount of oxidized ammonia (panel $\mathrm{C}$ ) as a function of water content in surface sediments (white symbols) and deep sediments (black symbols) at running water (circle), short-term pool (triangle down), long-term pool (square), short-term dry (diamond), and long-term dry (triangle up) sites. Mean values and standard errors are shown. Results from GLS models with sediment layer as treatment and water content as covariate are shown. Statistically significant effects $(p<0.05)$ are marked in bold. Straight lines describe the fits of the GLS models between the response variables and the interaction between the factor and the covariable. Non significant effects are omitted.

Figure 3: Map of the fully expanded Fuirosos stream network and its catchment (panel A); dynamics of the nitrate flux at the Fuirosos catchment outlet during the days following flow reconnection used to calculate total nitrate export during a typical first flush event (data adapted from von Schiller et al. 2011, panel B); total nitrate export during a first flush event calculated from the data in panel B; and estimated contribution of nitrate stored in dry sediments estimated from the upscaling of the data reported in the present study (panel C).

This article is protected by copyright. All rights reserved. 

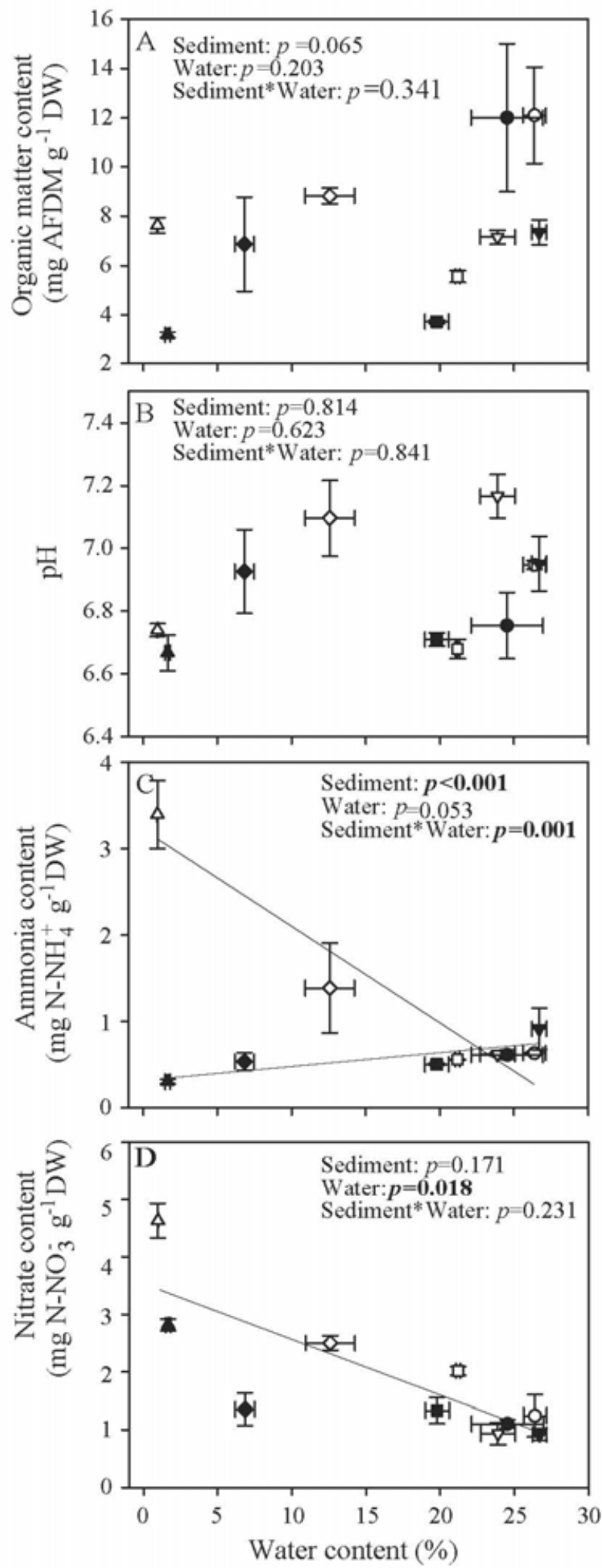

This article is protected by copyright. All rights reserved. 

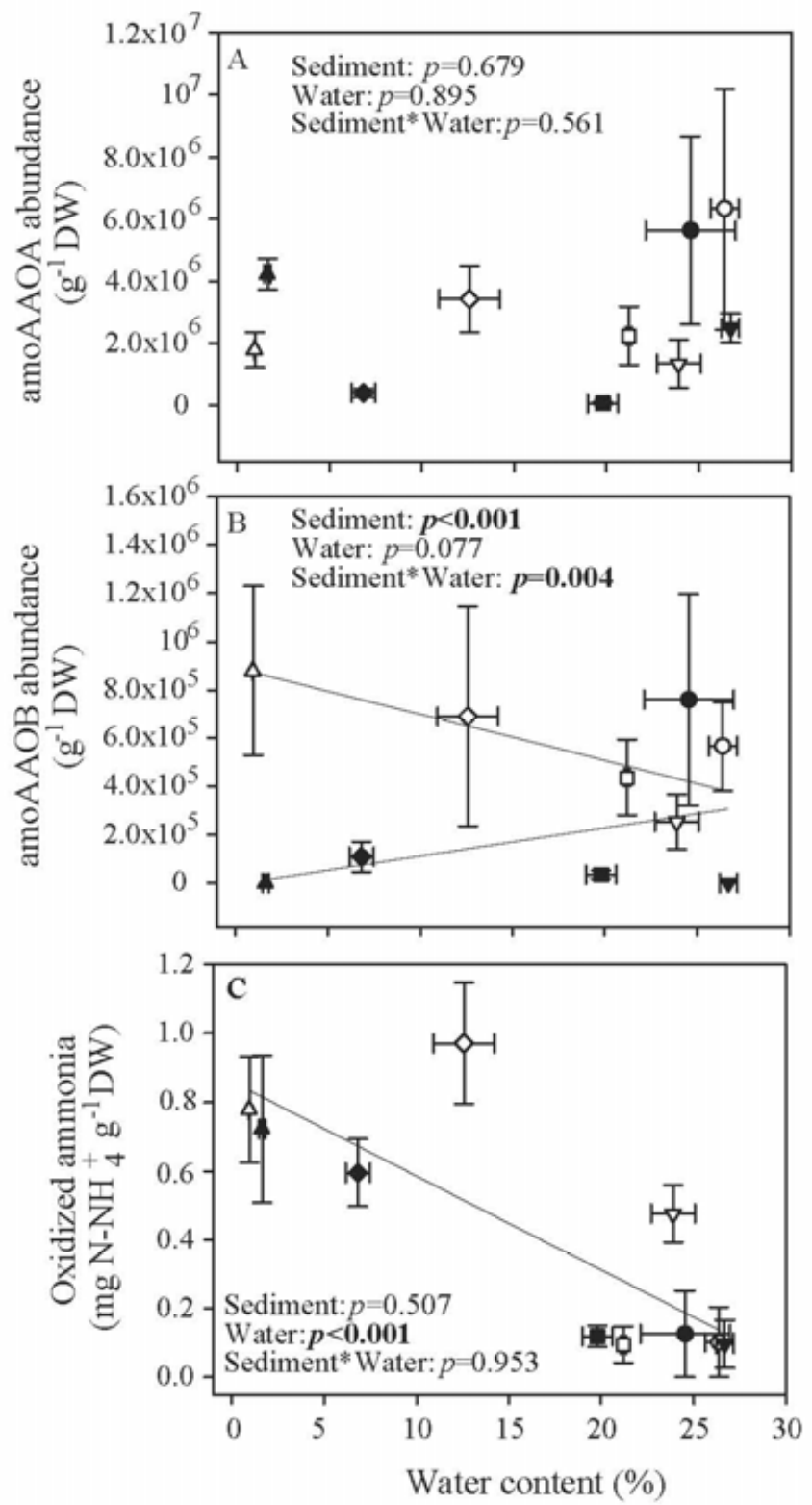

This article is protected by copyright. All rights reserved. 

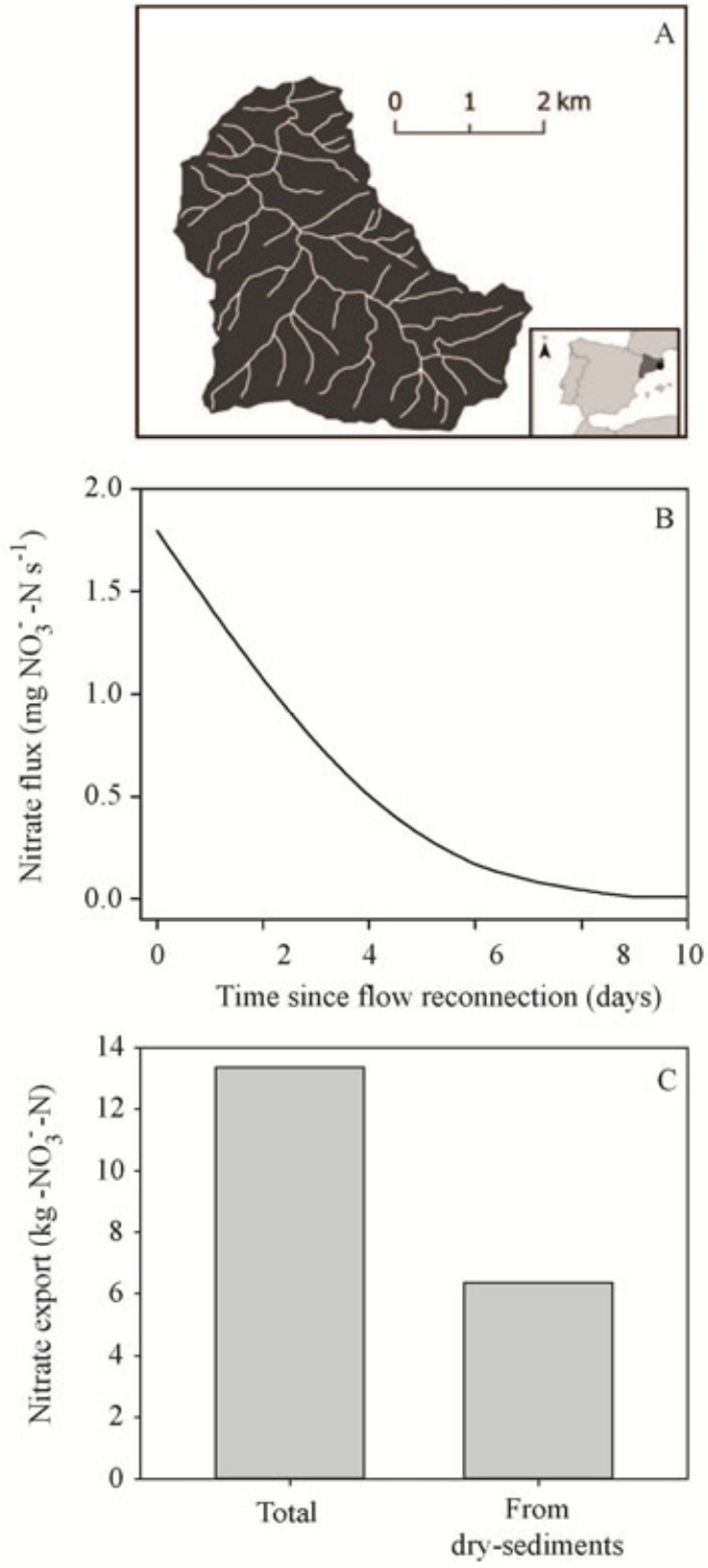

This article is protected by copyright. All rights reserved. 